\title{
Responsabilidade e autenticação no exercício da Ontopsicologia ${ }^{1}$
}

\begin{abstract}
Alécio Vidor ${ }^{2}$
Todos nós sabemos que o homem apreendeu, de modo prioritário, o ensino de um outro como meio de regular a interioridade da própria existência. Esse fato exclui a própria percepção em senso visceral.

A Ontopsicologia, uma ciência que também pode ser apreendida estudando os conteúdos externos, escritos ou gravados, e estes se fazendo testemunho de quem os elaborou. Isto é uma vantagem, pois permite o conhecimento de seu autor. Porém, o próprio criador da Ontopsicologia insiste que tal conhecimento (o da Ontopsicologia) pode ser atingido mediante evidência própria, desde que se aprenda a decifrar gradualmente todas as informações organísmicas. Portanto, para aprender essa ciência, nossa alma compilou um só livro: o corpo de cada um. É através dele que cada um pode obter a evidência da própria identidade inteligente da vida humana.

A formatura confere o diploma aos que efetuaram o estudo dos textos escritos ou gravados. Porém, o título de ontopsicólogo, para os que querem prosseguir, o diploma responsabiliza ter que aprender e identificar as variáveis informações que passam pelos receptores e agentes do próprio organismo visto ser esse o caminho para entender a linguagem do mundo-da-vida e da própria natureza. Este percurso é necessário embora não seja obrigatório para construir o próprio projeto de vida e a própria identidade.

A tarefa de conhecer a si mesmo passa pelos instrumentos da Ontopsicologia, mas é árdua, longa, humilde, silenciosa. O saber quem sou passa pelos reflexos de como eu existo e fui constituído organicamente e pela minha alma. A tarefa é para aqueles poucos que querem. Toda a própria grandiosidade está situada nesta realidade onde Eu Sou. Essa realidade não se atinge por convicção, por presunção ou pressuposição de sabê-la sem a

\footnotetext{
${ }^{1}$ Discurso proferido em ocasião da Formatura da $1^{\text {a }}$ Turma do Bacharelado em Ontopsicologia realizada na Antonio Meneghetti Faculdade (AMF), aos 19 de outubro de 2019. Adaptado para ensaio pelo editor-chefe, revisado e aprovado pelo autor para publicação.

${ }^{2}$ Formação ou titulação do autor, instituição de ensino (abreviatura do nome da instituição), cidade, estado, e-mail, sendo que estes devem estar em ordem alfabética do primeiro nome e por extenso.
} 
leitura contínua do aparato orgânico próprio acrescido das linguagens psíquicas. E a linguagem psíquica se mostra para ser compreendida com consciência inteligente e não com repetição do já sabido.

A evidência não se obtém com aprovação alheia e nem por críticas ou convenções externas. As ciências que nos transmitiram sempre se apoiaram na percepção incompleta, servindo-se dos sentidos externos, e unindo os mesmos a convicção que o conhecimento consciente acontece em coincidência com o mundo físico. Esta convenção consagrou a objetividade fisicalista com base no saber científico oficial, excluindo o conhecimento do mundo-da-vida.

A Ontopsicologia, primeiro procura ampliar o raio de percepção biológica para integrar no saber o processo da atividade psíquica. Pode-se perceber que o próprio organismo é dotado de órgãos diferenciados, de receptores, de transmissores, de informações, e que por isso o corpo traduz as informações através dos seus reflexos. Existem nove critérios biológicos que cada ser humano possui: os cinco sentidos externos e, através de suas variações, atuam e ativam o sistema nervoso central, o sistema neurovegetativo, o sistema endócrino e o sistema imunológico. Há uma conexão de continuidade entre sentidos externos e os quatro sistemas internos, basta notar a ressonância do sistema nervoso e, através dos órgãos genitais, que são antenas, sentir as informações que acontecem no sistema neurovegetativo e glandular, para aprender e perceber que há uma ação unitária de todos os órgãos.

Quem vê e lê a continuidade circular de informação que envolve o conjunto orgânico, resgata a exatidão funcional do organismo e de sua ordem. Percebendo esta ordem no final do conjunto, torna-se evidente na base, no ganho, ao princípio ordenador que ordena um conjunto, e esse princípio é um agente imanente e inteligente e se denomina alma ou Em Siôntico. Além dos canais orgânicos de informações, existem os chakras, que sendo presença energética fotônica, informam motivações pré-formadas pela cultura, e emoções distônicas ou originais definidas pela ordem da natureza.

As informações bioenergéticas, quando desconhecidas, acabam estruturando males no corpo, porém em antecipação a mente ou a alma, codifica em sonhos e símbolos da fantasia e as mensagens para precaver os males somáticos ou erros da existência.

Quando o eu ou a consciência se abre para integrar em conhecimento todas as informações do mundo-da-vida, que passam pelo seu transmissor orgânico, pode chegar à evidência de um grupo que fundamenta o saber. Isto foi denominado Visão Ôntica. A mente 
humana é uma analogia de uma inteligência transcendente, por isso o homem é dotado de uma forma de inteligência denominada intuitiva e, a seguir, lógico-racional.

A intuição colhe a intenção que emana do ser, do fundamento do saber, e a lógica faz as combinações e a coerência do saber científico, e a razão julga o valor com exatidão para corrigir as eventuais distorções e confirmar a intencionalidade do saber verdadeiro. Eu sei que falei mais para os formandos do que para a plateia, mas tentei traçar o caminho que leva à revisão crítica da racionalidade individual construída e a revisão crítica dos conhecimentos adquiridos para ajustar a bússola que direciona o valor de realização da existência. 